\title{
THE RELATIONSHIP BETWEEN ONLINE CONVENIENCE, ONLINE CUSTOMER SATISFACTION, BUYING INTENTION AND ELECTRONIC WORD-OF-MOUTH
}

\author{
Phuong Viet Le-Hoang \\ Ho Chi Minh City Open University, Vietnam \\ E-mail: lehoangvietphuong@gmail.com
}

Submission: 1/19/2020

Revision: $2 / 11 / 2020$

Accept: 2/20/2020

\section{ABSTRACT}

The purpose of this research aims to explore, measure, and analyze the relationship between online convenience, online customer satisfaction, buying intention, and electronic word-of-mouth (E-WOM) of the customers via the Exploratory Factor Analysis (EFA) and three model regression. To conduct the research, the author distributed 300 surveyed questionnaires, and the author collected 285 valid respondents. The results showed that online convenience, which has seven dimensions about convenience, includes access, search, evaluation, attentiveness, transaction, possession, post-possession convenience affect online customer satisfaction. Furthermore, as a result, online customer satisfaction influences online buying intention and electronic word-of-mouth. Based on that, the research recommends the necessary solutions to improve the buying intention and encourage customers to do E-WOM. Besides, this research opens a new field for further research in Vietnam.

Keywords: Online convenience; Online customer satisfaction; buying intention; electronic word-of-mouth; convenience dimension 
DOI: 10.14807/ijmp.v11i7.1251

\section{INTRODUCTION}

The development of the Internet that has completely changed the lives of people and the business form small, medium, and large enterprises over the world; besides, the ecommerce industry was born as the indispensable. The e-commerce industry covers a wide range of socio-economic activities and brings significant benefits. Thanks to e-commerce, human life becomes more comfortable, and people can save time and money because of the flexibility, simplicity, and excellent applications of e-commerce.

Consumers quickly access and read the sharing of ideas and feelings of other individuals to compare and select the most of their benefits. Consumers can submit comments, ratings, and product reviews on websites, blogs, forums, social networking sites (Facebook, Twitter, Youtube,...). It has led to the creation of a diverse online word of mouth community that has a tremendous impact on businesses, retailers, and wholesalers.

E-commerce is a modern tool to help businesses penetrate the market better, collect market information quickly and timely; also, e-commerce helps trade activities take place faster with many utilities. Enterprises can also provide information about products and services to potential customers anytime, anywhere, when the customers use the Internet. It can be seen that e-commerce is overgrowing in many Asian countries, including Vietnam, it is considered to be born along with the mandatory development of the digital economy and information society.

Moreover, the expansion of shopping in many new industries in the online environment is prospective, and it tends to use e-commerce more in the future. So it is also easy to satisfy customers. For customers who spend money to use the services, they always consider which is the best for them. Customer satisfaction is a big question that the business needs to focus on, so the sellers and e-commerce site owners must identify the crucial factors that affecting customer satisfaction.

Currently, Ho Chi Minh City is the most dynamic city in Vietnam, and it has a high income, a high standard of living, and a high population density. It is required for e-commerce sites to provide products with good service quality, such as online convenience when shopping to be able to attract customers to shop online at their website. It makes a difference and an advantage over competitors.

When the customers feel satisfied by the online convenience, it will affect the online purchasing intention and encourage electronic word-of-mouth (E-WOM) of the customers 
DOI: 10.14807/ijmp.v11i7.1251

spreadly. Understanding the essentials and practicality of the above problem, the author conducted the research "The relationship between online convenience, online customer satisfaction, buying intention and electronic word-of-mouth.”

\section{LITERATURE REVIEW}

\subsection{Online convenience}

Today, online users can easily access to convenient services and products through the Internet, so they can do online shopping that meets their needs quickly and easily. The online shopping has unique advantages. Notably, customers can easily access product information from various sources. The online form provides a wide variety of products and services, especially clothing, electronics, toys, and cosmetics. Most of the e-commerce sites allow customers to rate and review products after purchase, so the other customers can see the rate and review and decide to buy products or services.

Researchers indicated that online shopping brings many benefits such as the convenience of purchase, ease of product selection, ease of use as well as online shopping process, or delight of customers when making online transactions. Buyers can receive the benefit from e-commerce shopping such as the speed, shopping efficiency, lower costs, and 24-hour service and on-site support (LAW; HSU, 2006).

Meixian (2015) showed some of the previous views, and finally acknowledged three significant benefits associated with online shopping behavior: (1) Price benefits; (2) available benefits; and (3) recreational benefits. Besides, Tsai and Wu. (2011) recognize that the perceived of usefulness, the ability to personalize and customize the product benefits through online group shopping gives many benefits for customer.

\subsection{Electronic Word-Of-Mouth (E-WOM)}

Electronic word-of-mouth is a positive or negative comment created by both old customers, current customers, and potential customers about a product, a service, a brand, or a business. Individuals, community groups, or organizations generate these comments via the Internet (HENNIG-THURAU et al., 2004). Consumers feel that other consumers perceive the source of information, and electronic word-of-mouth does not come from companies (GOYETTE et al. 2010).

E-WOM is an interpersonal communication about online mechanisms. It is an exchange of non-commercial and informal conversations using internet platforms (GOYETTE et al., 
DOI: 10.14807/ijmp.v11i7.1251

2010). E-WOM is a collective term that describes the delivery of information related to goods or services exchanged from buyer to buyer through the web.

\subsection{The effects of E-WOM}

The origin of E-WOM from a consumer is often unknown, making it difficult to determine the quality of information and the reliability of the information posted (CHATTERJEE, 2001). E-WOM is scalable, and the transmission speed is high. The main difference between E-WOM and traditional WOM is that the effect of traditional WOM is usually limited to a local area. In contrast, the E-WOM impact can far exceed local communities because consumers can access reviews anywhere in the world.

Most of the information on the Internet is presented or displayed in text form, and therefore, the information will be stored for an indefinite period (PARK; LEE, 2009). E-WOM can measure more easily than word-of-mouth (LEE et al., 2008; PARK; KIM, 2008). E-WOM can be viewed and read by anyone, anytime, and anywhere if the user has access to the Internet (CHEN; XIE, 2008). E-WOM is a useful and influential source for consumers when they need information. (CHATTERJEE, 2001). Thus the effect of E-WOM on the receiver will be affected by the factors of the communicator (sender of information), stimulus (message), and characteristics of the recipient.

\subsection{Behavior intention (buying intention)}

Consumer behavior in the context of online shopping manifests in the actions of continuing to buy, repurchases, evaluation, and feedback to the seller, introducing to others when satisfied, and get the information by E-WOM. The behavior of consumers when buying online is the same as that of traditional purchases; some of the main differences being the shopping environment and marketing communications (CHAYAPA et al., 2011).

In the research of Azjen (1991), Azjen and Fishbein (1975) also mentioned influencing factors including attitude, buying intent, personal factors, behavioral belief, subject norms, Control beliefs, and perceived behavioral control. Jayendra and Kim (2012) proposed a research model of six factors affecting consumers' intention to buy online: Awareness of ease of use, perceived usefulness (from technology accept model, DAVIS 1989), financial risk awareness, product risk awareness, convenience risk perception, after-sales policy.

According to Li and Zhang (2002), factors that influence online shopping behavior include the external environment, demographics, personal characteristics. According to Forsythe et al. (2006), online shopping has advantages such as shopping quickly, no need to 
DOI: 10.14807/ijmp.v11i7.1251

visit the store, quickly find the product that the customer needs. Also, the customer can buy products anywhere.

\section{HYPOTHESES DEVELOPMENT}

This research uses the seven dimensions (access convenience, search convenience, evaluation convenience, attentiveness convenience, transaction convenience, possession convenience, post-possession convenience) of online convenience of Duarte et al. (2018). However, there is a difference between this research and the research of Duarte et al. (2018). According to Duarte et al. (2018), seven dimensions affect online convenience, and online convenience affects online customer satisfaction. The research of the author indicated that seven dimensions directly affect online customer satisfaction.

Access convenience is measured by accessibility, and as a result, consumers have easy access to retailers (BERRY et al., 2002). Convenient access is a profoundly crucial aspect of local convenience, because if a consumer is unable to access the retailer, then the consumer will never have a chance to get the products that they want.

Traditional retailers can improve access convenience by placing the store in an accessible location that closes to most consumers (BERRY et al., 2002). In contrast, online retailers can certainly provide convenient access when the store location becomes an unimportant factor (ROHM; SWAMINATHAN, 2004), and consumers can shop online from any location, at any time of day, even consumers can buy seven days a week.

The accessibility of websites is considered to be an essential factor for consumers to realize the convenience of online shopping (KING; LIOU, 2004). Compared to traditional shopping, online shopping reduces the time spent on transportation/effort to place, time/effort for parking, and time/effort on parking foot to the store (BHATNAGAR et al., 2000). Convenient access helps retailers get off to a good start with busy consumers (SEIDERS et al., 2000). By the way, the author proposes the following hypothesis:

- H1: Access convenience has a positive effect on online customer satisfaction.

The Internet search allows retailers to improve their business relations and build advertising strategies. Through this tool, consumers can view the product on their computer screens and visualize how the products can fit their needs. Consumers can also participate in online discussions with other consumers about the products and services they seek and compare prices easily. 
DOI: 10.14807/ijmp.v11i7.1251

These types of flexibility (navigation, selection, and product availability) provide psychological benefits by avoiding crowds, reducing waiting time, and spending less effort in going to physical stores (BEAUCHAMP; PONDER, 2010). It is why convenient search is vital for retailers to improve their website. Convenience is an intuitive, easy-to-handle, and attractive design tool to guide customers in decision making. By doing so, retailers are improving the convenience of searching for speed and ease of use so that consumers identify and select the products they want to buy online (BEAUCHAMP; PONDER, 2010).

Access convenience reduces the time and effort required to reach a retailer, while search convenience helps consumers through the shopping process by assisting them in making their decisions. Consumers often face a wide range of product classifications and less time to make decisions. Therefore, online search engines of retailers must be available to provide full written information about the product. Retailers are more efficient at enabling customers to search for products. The customer search process is faster and easier through shopping experience (BERRY et al., 2002). Therefore, the author wants to propose the following hypothesis:

- H2: Search convenience has a positive effect on online customer satisfaction.

Evaluation convenience is related to the availability of product description details in an easy-to-understand manner by using various presentation features. For instance, text presentation types, graphics, and videos, on the company's website (JIANG et al., 2013). The categories for presenting this product allow consumers to familiarize themselves with the product and compare it with others.

At the same time, consumers make the purchase process faster. Besides, in recent years, diverse product categories and information details are easily accessible with just one click. Therefore, online shoppers are more sensitive than ever to assess convenience (JIANG et al., 2013). Accordingly, the author proposes the following hypothesis:

- H3: Evaluation convenience has a positive effect on online customer satisfaction.

Luedi (1997), Madu and Madu (2002) argued that the intense competition in the market of online retail websites directly exposing the product or service portfolio on the Web is not sufficient to ensure their existence. Attentiveness convenience refers to the extent to which online retailers provide personalized services to their customers (JUN et al., 2004).

Although a website is a personal platform of business that used to retain customers, a company needs to distinguish the products and services from competitors based on 
DOI: 10.14807/ijmp.v11i7.1251

personalized services for customers (JUN et al., 2004). Online customers expect customized attention, customizing their needs and areas for customer questions and discussion. Due to this fact, many online retailers are providing decision support (i.e., recommendation or shopping bots, human assistant) to better provide personalized services (BEAUCHAMP; PONDER, 2010). In this way, this study proposes the following hypothesis:

- H4: Attentiveness convenience has a positive effect on online customer satisfaction.

Convenience in transactions is defined as that consumers can make or modify their transactions quickly and easily (BEAUCHAMP; PONDER, 2010). Customers can buy online products with one-click payments, and easy return policies will get higher ranking for convenient deals (SEIDERS et al., 2000) because waiting to pay is an undeniable negative experience (BERRY et al., 2002).

At traditional stores, shoppers often spend time waiting for the queue to complete a transaction, which can be suspicious for companies. It leads to a negative impact on overall service evaluation (KUMAR; KASHY AP, 2018). One of the main benefits of online shopping is that customers never have to queue (WOLFINBARGER; GILLY, 2001). Online shoppers are in virtual check-out and payment where they can complete transactions themselves (DE KERVILER et al., 2016).

The easily complete or modify orders are crucial. The transaction with inconvenience may prevent a customer from buying a retailer's product in the near future (BERRY et al., 2002). Concerns about privacy, the fear of insecure trading, the risk of losing money have been argued as the most significant inhibitors for online shopping (JAVADI et al., 2012), and that is why easy, safe, and convenient online payment method is essential for customers. From the above arguments, the author wants to propose the following hypothesis:

- H5: Transaction convenience has a positive effect on online customer satisfaction.

Possession convenience is the speed and comfort that the customer can buy the needed products. As a result, to make the possession convenient for customers, there is crucial when the business determines the products in stock and delivers the products on time (BEAUCHAMP; PONDER, 2010). According to Jiang et al. (2013), This aspect involves consumers aware of the time and effort spent to own what they want.

Customers feel comfortable to shop online, while customers who shop directly at the store have to bear the burden of carrying goods at physical stores. Therefore, for heavy-weight 
DOI: 10.14807/ijmp.v11i7.1251

goods or lots of bulk items, customers prefer to buy online rather than traditional goods to avoid dealing with physical efforts (JIANG et al., 2013). Online buyers must wait for their orders to be processed and shipped to receive their goods.

The waiting time for order processing and delivery is a non-monetary cost associated with online shopping (BEAUCHAMP et al., 2010). One of the primary motivations for purchasing in stores is the ability to leave the store with the intended product (ALBA et al. 1997; ROHM; SWAMINATHAN, 2004). Therefore, the author proposes the following hypothesis:

- H6: Possession convenience has a positive effect on online customer satisfaction.

The importance of post-possession convenience (convenience after purchase) has been emphasized in recent years because of the difficulties consumers have encountered in returning products purchased over the Internet (SEIDERS et al., 2002). Post-possession convenience becomes essential after exchanging services and involves consumers realizing the time and effort spent when re-communicating with a company after purchasing the intended product (SEIDERS et al., 2002).

Factors determining convenience after owning a product (also known as postpossession convenience) are records/reports for consumers who need repair, maintenance, or exchange of products (BERRY et al., 2002). Sometimes consumers contact the seller because of an unrecognized error in the initial purchase.

Other reasons for contacting the retailer also include transaction issues, customer complaints, defective products or services, and customers changing their minds (SEIDERS et al., 2007). Post-possession convenience efforts may also influence other factors, affecting customer purchasing stages (SEIDERS et al., 2002). For example, a service error may affect evaluation convenience if consumers are provided with unrealistic information. Access convenience may be concerned if the online connection fails.

Transaction convenience will be undervalued if prices are inaccurate or price manipulation leads to a delay in the buying behavior of consumers (SEIDERS et al., 2002). In general, less time and effort is needed to deal effectively with a failed service; the higher the perceived convenience in online transactions (SEIDERS et al., 2002). Therefore, the hypothesis is as below:

- H7: Post-Possession convenience has a positive effect on online customer satisfaction. 
DOI: 10.14807/ijmp.v11i7.1251

Following the model presented by Zeithaml et al. (1996), intentional behavior can be perceived by means such as intent to acquire, word-of-mouth, loyalty, complaining, sensitivity behavior, perceived price level. A high quality of service (as perceived by the customer) often results in positive behavioral intent.

In contrast, the low quality of the service tends to result in negative behavioral intention. An experienced consumer of online shopping will have a significant influence on customers who intend to buy in the future for online shopping (JAYAWARDHENA et al., 2007). Therefore, research indicates that the more positive a customer experience is, the more likely it is that customers are reusing store services.

This argument is similar to that of Zeithaml et al. (1996), they emphasize that the intention of behavior is related to a customer who decides to stay or leave a brand/company. From the comments discussed, it can be understood that convenience influences consumer satisfaction, and therefore online satisfaction influences purchasing behavior. Consequently, the hypothesis is as follow:

- H8: Online customer satisfaction has a positive effect on online buying intention.

Traditional word-of-mouth (WOM) is a communication method described initially as a means of sharing ideas and opinions related to the products and services that people purchased (GRUEN, 2006). WOM has been shown in situations to be more effective than traditional marketing tools and some types of advertising (KATZ; LAZARFELD, 1955; ENGEL et al., 1969). However, word-of-mouth has evolved into a whole new form through modern technology. It is nominated as electronic word-of-mouth (E-WOM).

Hennig-Thurau et al., (2004) refer to E-WOM as any positive or negative statements made by potential customers, previous customers about a product or company. By word-ofmouth is provided to many people by the information of individuals or groups via the internet. The significant growth in online social networking has dramatically expanded the potential impact of electronic word-of-mouth (E-WOM) on consumer purchasing decisions. The digital platform is composed of blogs, vlogs, discussion forums, social networking sites, review of sale websites. Indeed, word-of-mouth has found a new way to assert its value in marketing products in new forms of electronic communication (GRUEN, 2006).

E-WOM is an online consumer review that includes analytics and comments created and posted by customers who have the experience of products. Four factors that affect the E- 
DOI: 10.14807/ijmp.v11i7.1251

WOM adoption of the online customers are the trust of eWOM news source, the quantity of eWOM, the quality of eWOM, and consumer expertise (LE-HOANG, 2020).

Online shoppers always read reviews and experiences of other shoppers before they buy products online. Millions of people have access to an online review, and this is the power of EWOM (PARK et al., 2011). In general, consumers find it necessary to know others' opinions before/while/after making purchasing decisions.

They talk and discuss their purchase intention with family members and friends on the Internet. The customer awareness of the influence of others such as family, co-workers or media (LE-HOANG et al., 2019). Customers who have a pleasant experience or are satisfied with a retailer are more likely to do positive reviews through E-WOM (DUARTE et al., 2018). As a result, the customers are most likely to be affected by make decisions because they interact and communicate with others. (PARK et al., 2011). The hypothesis is as below:

- H9: Online customer satisfaction has a positive effect on Electronic Word-Of-Mouth (E-WOM).

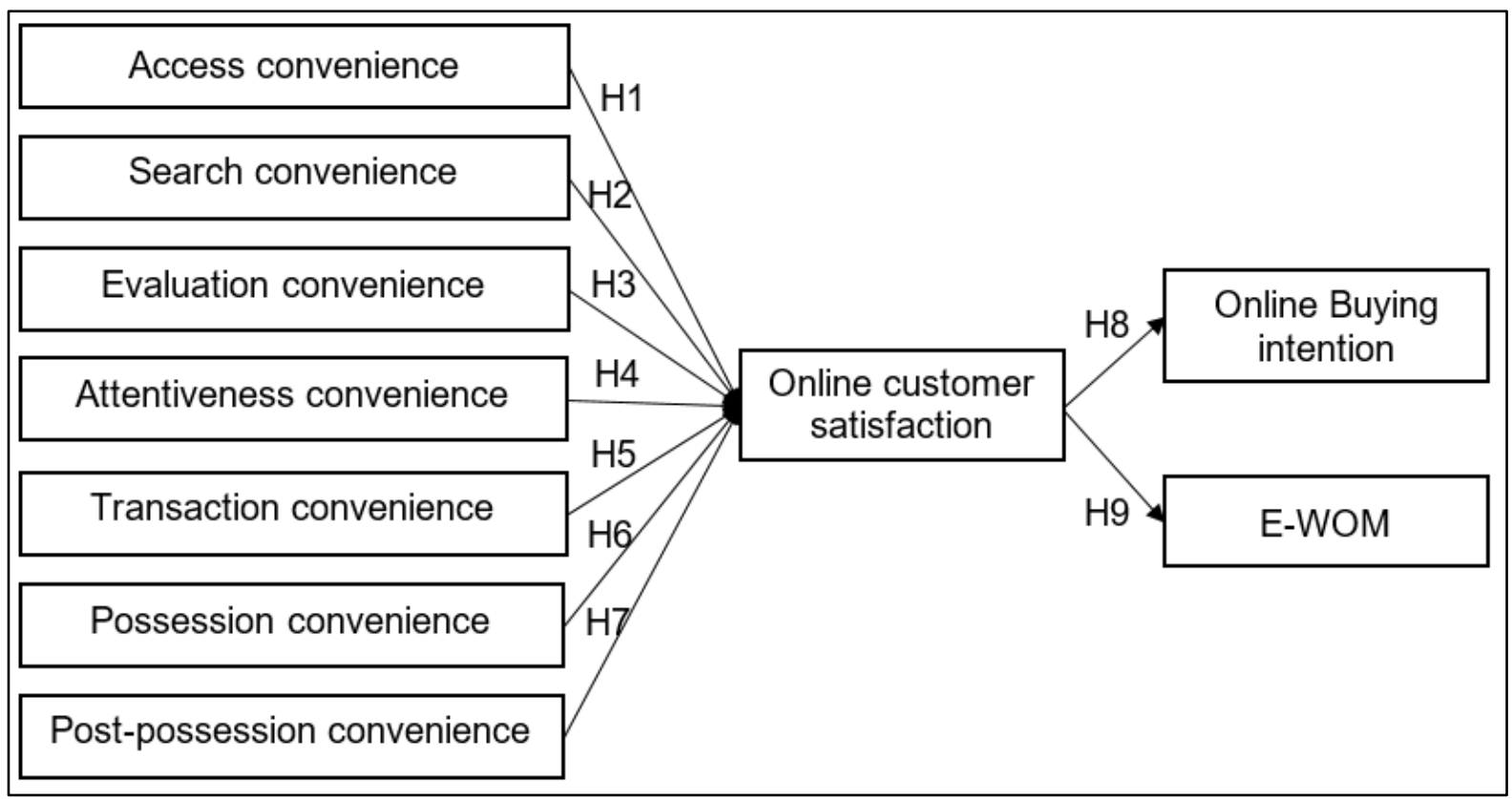

Figure 1: Proposed research model of the author

\section{METHODOLOGY}

This research uses the qualitative research method via group discussions and expert discussions to build research models, scales, questionnaires, and preliminary surveys to complete research models before issuing the questionnaire. The author surveyed the vicechairman of the Vietnam E-Commerce Association (VECOM), chairman of the Vietnam Marketing Association (VMA), surveyed three members of the Executive Committee of 
DOI: 10.14807/ijmp.v11i7.1251

VECOM and three members of the Executive Committee of VMA to complete the group discussion.

Quantitative research method based on information collected from the online customers who live in Ho Chi Minh City. Likert scale with five levels, namely strongly disagree, disagree, neutral, agree, and strongly agree, is used to measure the impact of factors affecting online customer satisfaction, and this research uses the convenient sampling method. Hair et al. (2014) pointed out that when the study uses the Likert scale five levels with the $\mathrm{n}$ variables, the study should ensure a minimum sample size of $5^{*} n=5 n$. To ensure the quality of the sample, the author decided to get from 250-300 questionnaires.

In quantitative research, the author assessed for reliability through Cronbach's Alpha coefficients, EFA method, and three regression models to find the relationship between seven convenience dimensions, online customer satisfaction, buying intention, and electronic wordof-mouth.

The author conducts an online survey on December 2019 by sending survey questionnaires to relatives, friends, and colleagues via applications such as Messenger, Zalo, Email, Facebook for people to do online surveys about the relationship between online convenience, online customer satisfaction, intention to buy, and electronic word-of-mouth (EWOM).

The author sends the survey link through the four applications mentioned above. When the author collected all 300 responses, the author closed the survey link and did not conduct the survey. Fifteen respondents were not valid for a variety of reasons. Six respondents answered incompletely; while, four respondents answer all of the questions with strongly disagree. Five responses are not valid in science.

The reason is that the component scales are around 2-3 values (Likert level), and the total scales are 5. Finally, the author obtained the online survey results with 285 respondents with valid answers and used for conducting Cronbach Alpha, EFA, and regression.

\section{ANALYSIS AND RESULTS}

\subsection{Reliability test: Cronbach's Alpha}

According to Nunnally and Bernstein (1994), the condition to accepting variables is that Corrected Item - Total Correlation is equal or greater than 0.3 and Cronbach's Alpha if item deleted is equal or greater than 0.7. According to Hair et al. (2014), new studies can accept 
INDEPENDENT JOURNAL OF MANAGEMENT \& PRODUCTION (IJM\&P)

http://www.ijmp.jor.br

v. 11, n. 7, November - December 2020

ISSN: 2236-269X

DOI: 10.14807/ijmp.v11i7.1251

that Cronbach's Alpha if item deleted is equal or greater than 0.6. Therefore, the remaining items satisfy the condition (see the table 1 below), so this can be used for analyzing Exploratory Factor.

Table 1: Constructs, corrected item - total correlation and Cronbach Alpha

\begin{tabular}{|c|c|c|c|}
\hline Items & Constructs & $\begin{array}{c}\text { Corrected } \\
\text { Item - Total } \\
\text { Correlation }\end{array}$ & $\begin{array}{c}\text { Cronbach's } \\
\text { Alpha if item } \\
\text { deleted }\end{array}$ \\
\hline \multicolumn{4}{|c|}{ Access convenience - Cronbach’s Alpha = $\mathbf{0 . 8 8 9}$} \\
\hline AC1 & The website operates $24 / 24$, so I can shop whenever I want & 0.790 & 0.835 \\
\hline AC2 & I can order products wherever I connected the internet & 0.746 & 0.872 \\
\hline AC3 & The website is always accessible & 0.841 & 0.814 \\
\hline \multicolumn{4}{|c|}{ Search convenience - Cronbach’s Alpha = 0.855} \\
\hline SC1 & $\begin{array}{l}\text { I can quickly go to the links within site to find the } \\
\text { information I am looking for }\end{array}$ & 0.711 & 0.810 \\
\hline SC2 & I can find what I want without having to look elsewhere & 0.645 & 0.837 \\
\hline SC3 & The website provides useful information & 0.712 & 0.809 \\
\hline SC4 & $\begin{array}{l}\text { It's easy to get the information I need to make my purchase } \\
\text { decisions }\end{array}$ & 0.722 & 0.805 \\
\hline \multicolumn{4}{|c|}{$\begin{array}{l}\text { Evaluation convenience - Cronbach's Alpha }=\mathbf{0 . 8 2 6} \\
\end{array}$} \\
\hline EC1 & The website provides detailed product specifications & 0.707 & 0.739 \\
\hline EC2 & $\begin{array}{l}\text { The website uses a combination of content and images in } \\
\text { the product information }\end{array}$ & 0.693 & 0.755 \\
\hline EC3 & $\begin{array}{l}\text { The website provides enough information to identify the } \\
\text { various products }\end{array}$ & 0.658 & 0.784 \\
\hline \multicolumn{4}{|c|}{ Attentiveness convenience - Cronbach's Alpha $=\mathbf{0 . 8 1 1}$} \\
\hline ATC1 & The website has given me personal attention & 0.678 & 0.734 \\
\hline ATC2 & $\begin{array}{l}\text { The website has a messaging area for questions and } \\
\text { comments of the customer }\end{array}$ & 0.621 & 0.786 \\
\hline ATC3 & $\begin{array}{l}\text { I have received a personal thank you message via email or } \\
\text { other media after I placed an order from the Website }\end{array}$ & 0.706 & 0.694 \\
\hline \multicolumn{4}{|c|}{ Transaction convenience - Cronbach's Alpha $=0.853$} \\
\hline TC1 & The payment process is fast & 0.701 & 0.809 \\
\hline TC2 & My purchase was completed easily & 0.689 & 0.814 \\
\hline TC3 & $\begin{array}{l}\text { It does not take long to complete the purchase process at } \\
\text { the website }\end{array}$ & 0.703 & 0.810 \\
\hline TC4 & I feel safe to provide my personal and private data & 0.684 & 0.817 \\
\hline \multicolumn{4}{|c|}{ Possession convenience - Cronbach’s Alpha = 0.831 } \\
\hline PC1 & I got exactly what I wanted & 0.715 & 0.761 \\
\hline PC2 & My order was delivered on time & 0.617 & 0.805 \\
\hline PC3 & Products are not damaged on delivery & 0.642 & 0.794 \\
\hline PC4 & I got all the items that I ordered & 0.662 & 0.785 \\
\hline \multicolumn{4}{|c|}{ Post-Possession convenience - Cronbach’s Alpha $=\mathbf{0 . 8 4 0}$} \\
\hline PPC1 & $\begin{array}{l}\text { The website is interested in exchanging and returning } \\
\text { products to retailers }\end{array}$ & 0.725 & 0.756 \\
\hline PPC2 & $\begin{array}{l}\text { The website pays attention to the timely return and } \\
\text { exchange of products }\end{array}$ & 0.663 & 0.816 \\
\hline PPC3 & $\begin{array}{l}\text { The retailer quickly resolves any post-purchase problems } \\
\text { that I encounter }\end{array}$ & 0.723 & 0.758 \\
\hline \multicolumn{4}{|c|}{ Online customer satisfaction - Cronbach’s Alpha $=\mathbf{0 . 8 2 3}$} \\
\hline OCS1 & Shopping online is an enjoyable experience & 0.689 & 0.744 \\
\hline OCS2 & $\begin{array}{l}\text { I am satisfied with my previous online shopping } \\
\text { experience }\end{array}$ & 0.731 & 0.702 \\
\hline OCS3 & I am delighted when doing the transaction on the website & 0.616 & 0.817 \\
\hline \multicolumn{4}{|c|}{ Buying intention - Cronbach’s Alpha = 0.787} \\
\hline BI1 & I will continue shopping online at this website & 0.593 & 0.747 \\
\hline
\end{tabular}


INDEPENDENT JOURNAL OF MANAGEMENT \& PRODUCTION (IJM\&P)

http://www.ijmp.jor.br

v. 11, n. 7, November - December 2020

ISSN: 2236-269X

DOI: 10.14807/ijmp.v11i7.1251

\begin{tabular}{|c|l|c|c|}
\hline BI2 & I encourage others to shop online at this website & 0.686 & 0.646 \\
\hline BI3 & I will use this website more often to make online purchases & 0.603 & 0.737 \\
\hline \multicolumn{1}{|c|}{ Electronic Word-Of-Mouth - Cronbach's Alpha = 0.808 } \\
\hline EW1 & $\begin{array}{l}\text { I always share my knowledge and information on online } \\
\text { sales websites }\end{array}$ & 0.629 & 0.767 \\
\hline EW2 & $\begin{array}{l}\text { I always read online consumer reviews when I do online } \\
\text { shopping }\end{array}$ & 0.689 & 0.706 \\
\hline EW3 & $\begin{array}{l}\text { I recommend people to buy products online from the } \\
\text { website where I usually buy them }\end{array}$ & 0.654 & 0.739 \\
\hline
\end{tabular}

\subsection{Exploratory Factor Analysis (EFA)}

Exploratory Factor Analysis (EFA) is an analytical technique which is aimed to reduce data, so it is beneficial for identifying variables by group. In the exploratory factor analysis, the author used Principal Component Analysis and Varimax rotation to group the components.

\subsubsection{Independent variables}

The results show that $\mathrm{KMO}$ is 0.786 and can make sure the requirement $0.5<\mathrm{KMO}<1$. Bartlett is 3844.04 with sig $=0.00$ (very small), so all of the variables are correlated together in each component. Total variance explained equals $74.713 \%$, and it is greater than $50 \%$; as a result, it can meet the requirement of variance explained. From this one, this research can conclude that variables can explain $74.713 \%$ in changing factors. Also, eigenvalue value equals $1.369>1$, and it is the fluctuation that can explain for each factor, so the extracted factors have a significant summarize in the best way. The rotated matrix in EFA show that the loading factor is higher than 0.55 , and it can divide into seven components by the following table:

Table 2: Rotated matrix

\begin{tabular}{|c|c|c|c|c|c|c|c|c|}
\hline \multirow{2}{*}{ Concepts } & \multirow{2}{*}{ Items } & & \multicolumn{6}{|c|}{ Component } \\
\hline & & 1 & 2 & 3 & 4 & 5 & 6 & 7 \\
\hline \multirow{4}{*}{$\begin{array}{l}\text { Transaction } \\
\text { convenience }\end{array}$} & TC1 & 0.841 & & & & & & \\
\hline & TC3 & 0.797 & & & & & & \\
\hline & TC2 & 0.761 & & & & & & \\
\hline & TC4 & 0.750 & & & & & & \\
\hline \multirow{4}{*}{$\begin{array}{c}\text { Search } \\
\text { convenience }\end{array}$} & SC1 & & 0.837 & & & & & \\
\hline & SC2 & & 0.799 & & & & & \\
\hline & SC4 & & 0.795 & & & & & \\
\hline & SC3 & & 0.787 & & & & & \\
\hline \multirow{4}{*}{$\begin{array}{c}\text { Possession } \\
\text { convenience }\end{array}$} & PC1 & & & 0.876 & & & & \\
\hline & PC4 & & & 0.785 & & & & \\
\hline & PC3 & & & 0.782 & & & & \\
\hline & PC2 & & & 0.770 & & & & \\
\hline \multirow{3}{*}{$\begin{array}{c}\text { Access } \\
\text { convenience }\end{array}$} & AC3 & & & & 0.875 & & & \\
\hline & AC2 & & & & 0.873 & & & \\
\hline & AC1 & & & & 0.846 & & & \\
\hline \multirow{3}{*}{$\begin{array}{l}\text { Post-Possession } \\
\text { convenience }\end{array}$} & PPC1 & & & & & 0.882 & & \\
\hline & PPC3 & & & & & 0.876 & & \\
\hline & PPP2 & & & & & 0.778 & & \\
\hline \multirow{3}{*}{$\begin{array}{c}\text { Evaluation } \\
\text { convenience }\end{array}$} & EC2 & & & & & & 0.825 & \\
\hline & EC1 & & & & & & 0.798 & \\
\hline & EC3 & & & & & & 0.775 & \\
\hline
\end{tabular}


INDEPENDENT JOURNAL OF MANAGEMENT \& PRODUCTION (IJM\&P)

http://www.ijmp.jor.br

v. 11, n. 7, November - December 2020

ISSN: 2236-269X

DOI: 10.14807/ijmp.v11i7.1251

\begin{tabular}{|c|c|c|c|c|c|c|c|c|}
\hline \multirow{3}{*}{$\begin{array}{l}\text { Attentiveness } \\
\text { convenience }\end{array}$} & ATC1 & & & & & & & 0.848 \\
\hline & ATC3 & & & & & & & 0.790 \\
\hline & $\overline{\text { ATC2 }}$ & & & & & & & 0.759 \\
\hline \multicolumn{2}{|c|}{ KMO } & & \multicolumn{6}{|c|}{0.786 (sig. $=0.000)$} \\
\hline \multicolumn{2}{|c|}{ Bartlett's } & & \multicolumn{6}{|c|}{3844.04} \\
\hline \multicolumn{2}{|c|}{ Eigenvalues } & 6.034 & 3.170 & 2.313 & 1.973 & 1.671 & 1.401 & 1.369 \\
\hline Total Varianc & Explained & 25.142 & 38.350 & 47.986 & 56.208 & 63.172 & 69.010 & 74.713 \\
\hline
\end{tabular}

\subsubsection{Dependent variable:}

The results show that KMO of OCS, BI, and EW is respectively $0.701,0.689,0.710$, and can make sure the requirement $0.5<\mathrm{KMO}<1$. Bartlett of OCS, BI, and $\mathrm{EW}$ are respectively 321.42, 253.20, 283.73 with sig $=0.00$ (very small and so sig<0.05), all of the variables are correlation together in each component. Total variance explained of OCS, BI, and EW respectively equals $73.97 \%, 70.18 \%, 72.43 \%$, and it is greater than $50 \%$; as a result, it can meet the requirement of variance explained. Besides, eigenvalues of OCS, BI, and EW respectively equal 2.219, 2.105, 2.173, and they are higher than 1 . It is the fluctuation that can explain each factor, so the extracted factors have a significant summarize in the best way. Finally, all of the variables have a loading factor that is greater than 0.55 and meet the requirement.

Table 3: Dependent variable, and testing

\begin{tabular}{|c|c|c|c|c|c|c|}
\hline \multirow[t]{4}{*}{ Criteria } & \multicolumn{2}{|c|}{$\begin{array}{l}\text { Online customer } \\
\text { satisfaction }\end{array}$} & \multicolumn{2}{|c|}{ Buying intention } & \multicolumn{2}{|c|}{$\begin{array}{l}\text { Electronic Word-Of } \\
\text { Mouth }\end{array}$} \\
\hline & OCS1 & 0.869 & BI1 & 0.816 & EW1 & 0.833 \\
\hline & OCS2 & 0.891 & BI2 & 0.874 & EW2 & 0.870 \\
\hline & OCS3 & 0.819 & BI4 & 0.823 & EW3 & 0.850 \\
\hline KMO & \multicolumn{2}{|c|}{0.701 (sig $=0.000)$} & \multicolumn{2}{|c|}{$0.689($ sig $=0.000)$} & \multicolumn{2}{|c|}{$0.710($ sig $=0.000)$} \\
\hline Bartlett's & \multicolumn{2}{|c|}{321.42} & \multicolumn{2}{|c|}{253.20} & \multicolumn{2}{|c|}{283.73} \\
\hline Eigenvalues & \multicolumn{2}{|c|}{2.219} & \multicolumn{2}{|c|}{2.105} & \multicolumn{2}{|c|}{2.173} \\
\hline Total Variance Explained & \multirow{2}{*}{\multicolumn{2}{|c|}{$\begin{array}{l}73.97 \% \\
0833\end{array}$}} & \multicolumn{2}{|c|}{$70.18 \%$} & \multicolumn{2}{|c|}{$72.43 \%$} \\
\hline Cronbach’s Alpha & & & \multicolumn{2}{|c|}{0.787} & \multicolumn{2}{|c|}{0.808} \\
\hline
\end{tabular}

\subsection{Three regression model}

From the EFA results, the author does compute the mean value of online customer satisfaction, buying intention, E-WOM, and seven dimensions of online convenience (access convenience, search convenience, evaluation convenience, attentiveness convenience, transaction convenience, possession convenience, post-possession convenience. Whereas:

AC: Access convenience (AC1, AC2, AC3)

SC: Search convenience (SC1, SC2, SC3, SC4)

EC: Evaluation convenience (EC1, EC2, EC3)

ATC: Attentiveness convenience (ATC1, ATC2, ATC3)

TC: Transaction convenience (TC1, TC2, TC3, TC4) 
INDEPENDENT JOURNAL OF MANAGEMENT \& PRODUCTION (IJM\&P)

http://www.ijmp.jor.br

v. 11, n. 7, November - December 2020

ISSN: 2236-269X

DOI: 10.14807/ijmp.v11i7.1251

PC: Possession convenience (PC1, PC2, PC3, PC4)

PPC: Post-possession convenience (PPC1, PPC2, PPC3)

OCS: Online customer satisfaction (OCS1, OCS2, OCS3)

BI: Buying intention (BI1, BI2, BI3)

OW: Electronic word-of-mouth (OW1, OW2, OW3)

The following formula can describe the regression model 1 in this research:

$\mathrm{OCS}=\beta 01+\beta 1 * \mathrm{TC}+\beta 2 * \mathrm{SC}+\beta 3 * \mathrm{PC}+\beta 4 * \mathrm{AC}+\beta 5^{*} \mathrm{PPC}+\beta 6^{*} \mathrm{EC}+\beta 7^{*} \mathrm{ATC}$

Then, the author computes the predicted value of OCS (OCSP) and the predicted value of OCS equals the actual value of OCS minus the error term.

So the regression model 2 is:

$\mathrm{BI}=\beta 02+\beta 8 * \mathrm{OCSP}$

Furthermore, the regression model 3 is:

$\mathrm{EW}=\beta 03+\beta 9 * \mathrm{OCSP}$

Table 4: Regression results (three model)

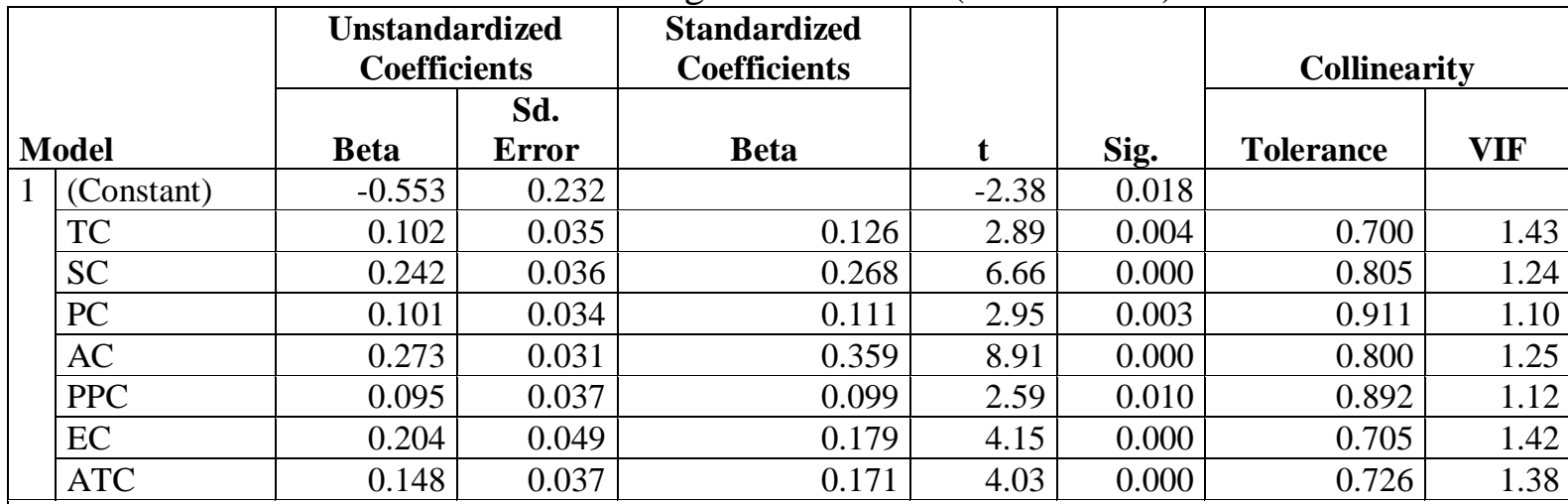

Dependent variable: Online customer safisfaction (OCS)

$\mathrm{R}^{2}=0.639$, Adjusted $\mathrm{R}^{2}=0.630$, Sig. $=0.000$

\begin{tabular}{|l|l|r|r|r|r|r|r|r|}
\hline 2 & (Constant) & 0.194 & 0.200 & & 0.97 & 0.334 & & \\
\cline { 2 - 9 } & OCSP & 0.594 & 0.049 & 0.757 & 19.48 & 0.000 & 1.00 & 1.00 \\
\hline
\end{tabular}

Dependent variable: Buying intention (BI)

$\mathrm{R}^{2}=0.573$, Adjusted $\mathrm{R}^{2}=0.571$, Sig. $=0.000$

\begin{tabular}{|l|l|r|r|r|r|r|r|r|}
\hline 3 & (Constant) & 0.335 & 0.239 & & 1.40 & 0.162 & & \\
\cline { 2 - 9 } & OCSP & 0.901 & 0.059 & 0.672 & 15.26 & 0.000 & 1.00 & 1.00 \\
\hline
\end{tabular}

Dependent variable: Electronic Word-Of-Mouth (E-WOM)

$\mathrm{R}^{2}=0.451$, Adjusted $\mathrm{R}^{2}=0.450$, Sig. $=0.000$

From the results of the regression model 1 show that the sig of all seven dimensions of convenience such as access convenience, search convenience, evaluation convenience, attentiveness convenience, transaction convenience, possession convenience, and post- 
DOI: 10.14807/ijmp.v11i7.1251

possession convenience have a significant statistic because the sig of them equals 0.00 (very small). As a result, these variables affect online customer satisfaction.

$\mathrm{R}^{2}$ value is 0.639 , and it means that $63.90 \%$ of the satisfaction of online customers is from seven factors, and $36.10 \%$ of that is from the factors which are outside of the model. The sig value is 0.000 , and it is less than 0.05 , so the research model is fit, and the variables which use in the model have a significant statistic. What is more, variance inflation factors (VIF) are too small, and these point out that there is no multicollinearity in this model, so all of the independent variables do not correlate together.

The multiple regression model 1 by unstandardized coefficients can be identified:

OCS $=-0.553+0.102 * \mathrm{TC}+0.242 * \mathrm{SC}+0.101 * \mathrm{PC}+0.273 * \mathrm{AC}+0.095 * \mathrm{PPC}+$ $0.204 * \mathrm{EC}+0.148 * \mathrm{AAC}$

The multiple regression model 1 by standardized coefficients can be identified:

$\mathrm{OCS}=0.126 * \mathrm{TC}+0.268 * \mathrm{SC}+0.111 * \mathrm{PC}+0.359 * \mathrm{AC}+0.099 * \mathrm{PPC}+0.179 * \mathrm{EC}+$ $0.171 * \mathrm{AAC}$

The results of the regression model 2 and 3 show that the OCSP (online customer satisfaction predicted value) affect buying intention and E-WOM. Because the model 2 and 3 meet all of the requirements of regression model, the multiple regression model 1 and 2 by unstandardized coefficients can be identified:

$$
\begin{aligned}
& \mathrm{BI}=0.757 * \mathrm{OCSP} \\
& \mathrm{EW}=0.672 * \mathrm{OCSP}
\end{aligned}
$$

\section{CONCLUSION}

\subsection{Access convenience}

The access convenience has the most substantial impact on customer satisfaction when shopping online (standardized beta $=0.359$ ). It is the factor that e-commerce sites need to focus on creating solutions to improve convenient access for the website. From there, businesses can attract and receive customer satisfaction reviews.

The e-commerce websites must fully meet the following factors: page load speed, standard website design (with Search Engine Optimization - SEO), valuable content, website compatible on all mobile devices: PC, smartphone, tablet. Besides, the website must ensure uptime throughout the day to create convenience for customers when they need to access 
DOI: 10.14807/ijmp.v11i7.1251

shopping. Keeping the online shop running will create favorable conditions for customers to have flexible shopping time when needed. Moreover, the website must ensure stability, network security so that the website is always in good working condition, and customers can access it at any time without any problem.

\subsection{Search convenience}

Search convenience is the second most influential factor in online customer satisfaction (standardized beta $=0.268$ ). Putting an e-commerce site on the top of search engines is a must, but optimizing the search engine on the website to make it convenient for customers is a more important job. There will be no massive amount of traffic every day if the website is too confusing, too difficult for customers to manipulate and find the products. Some solutions are more straightforward with ways to optimize search for an e-commerce website.

The navigation bar and filters: According to usability studies, it shows that the user's eyes naturally look from left to right, so place the navigation bar on the left; and add space for details on the left side of the screen. From there, customers can choose to expand the navigation bar into a drop-down box displaying subcategories. When users have followed the navigation, they will be taken to a page full of products. Website owners need to provide filter options that allow customers to quickly see their products - by price, color, material, most recently.

In addition to providing products with colorful, high-resolution images, remember to add unique, compelling descriptions. That will not only attract shoppers to click on the main product page more, but Google is also more likely to prioritize a unique product description over non-original content. Website owners make cross-links between product pages and categories. That way, shoppers will easily find related products, all of which make them spend more time on the e-commerce site and reduce bounce rates. Cross-linking is one of the most effective search methods for e-commerce customers, especially those browsing without having a clear purchase intent in mind.

Optimize the search box on the web: The search box can help to target customers when the e-commerce site has a large number of product pages. Depending on the effectiveness of this tool, the search will take shoppers to the full page of the corresponding product. However, the site should still entice users into the "task" of exploring the site. Consider using floating sidebars with the most popular products or categories that follow shoppers during a search or feed for sales, such as a social shopping page of Fab.com. E-commerce websites should always 
DOI: 10.14807/ijmp.v11i7.1251

be changing with featured products, sales, and content selection, so that online loyalty customers are more tempted to discover.

Create a natural search: Mention about the homepage, Google will crawl the data on the website with the most SEO, usually the homepage. Therefore, the pages that the website links to the homepage should be the most important. These pages may not necessarily reflect the navigation bar categories of the e-commerce website. It should be indexed for all the main pages, catalog pages, and even specific product pages of an e-commerce website. Use Google Webmaster Tools and Webmaster Central to learn how to effectively index pages, then track what users search and find in e-commerce pages.

Making optimizing search better: It is necessary to attach strategic keywords (including long keywords) to e-commerce websites. Use Google's free and paid keyword tool to estimate website traffic that can be expected from particular words and keyword phrases.

\subsection{Evaluation convenience}

Evaluation convenience is the third most strong factor that affects online customer satisfaction (standardized beta $=0.179$ ). Customers always want to make their comments, opinions, and reviews when they do online shopping at e-commerce sites. Therefore, in order to meet the needs as well as create interest and confidence for customers, e-commerce sites need to provide forms for customers to make reviews on the website itself.

Save customer comments: Positive and negative feedback from customers will be the most apparent evidence for the quality of e-commerce products. When buying online, customers often read reviews and product reviews to decide whether to buy or not. The website should publicize the compliments and criticism of customers right on the website to improve the trustworthiness and publicity of the website.

The website needs to provide detailed specifications of the products that the ecommerce business website sells. Include content and images in product information to create a convenient assessment for customers when shopping. Help customers understand the product information to buy. The e-commerce site also provides enough information to identify various products.

\subsection{Attentiveness convenience}

Attentiveness convenience is the fourth most effective factor for online customer satisfaction (standardized beta $=0.171$ ). One of the biggest problems customers that buy and 
DOI: 10.14807/ijmp.v11i7.1251

sell online products is the thoughtful convenience of e-commerce sites. E-commerce websites need to include features like product catalog management.

The website has a messaging area for customer questions and opinions. E-commerce sites may have to solve all customer complaints quickly and promptly. So the website needs to have software to manage and take care of customers. The storage of information and customer buying behavior is the basis for the website to devise effective marketing strategies. Also, ecommerce websites need add-ons that support multilingual support.

E-commerce sites need to have customer care service to take care of the customer before and after shopping at the site. The customer care service will take action to send personal notices with thanks via email or various media when customers shop at the website and update the status of the shipping process to customers.

\subsection{Transaction convenience}

Transaction convenience is the fifth influence factor that affecting online customer satisfaction (standardized beta $=0.126$ ). Nowadays, more and more e-commerce sites are competing with each other, so solutions to make a difference, usefulness, convenience in sales stages are focused on improving websites to attract customers and create a competitive advantage. One of the advantages that e-commerce sites need to pay attention to is building deals.

The payment process must be fast. The website needs to program the specific steps and simplify as much as possible so that the payment process between customers and the website takes place quickly. After adding products to the shopping cart, customers are required to confirm orders and proceed with the prepayment process via electronic card service or pay cash on delivery. The payment process takes place quickly and simply without bringing discomfort or hassle to customers shopping at the site.

Diversified payment methods: In order to create convenience for customers when paying for shopping expenses, the website needs to offer different forms of payment, ensuring flexibility and convenience for customers as usual via e-wallet, bank card linking with personal accounts, pay in cash after receiving goods.

The business must ensure the security of personal data information for customers. For payment and delivery to take place, customers are required to provide personal information such as contact phone number, address, gender, year of birth. Providing personal information is not simple and sometimes uncomfortable for the majority of customers. In order to create 
DOI: 10.14807/ijmp.v11i7.1251

peace of mind, trust customers when providing personal information, e-commerce sites need to ensure the confidentiality and privacy of customer information.

\subsection{Possession convenience}

Convenience ownership is the sixth most influential factor that affects online customer satisfaction (standardized beta $=0.111$ ). In order to improve the convenience of e-commerce sites, businesses need to do some solutions related to accuracy and delivery time.

Business needs to guarantee absolute accuracy for what customers order. E-commerce sites need to make sure that the delivery of products is the right product that customers shop on the site. Create customer satisfaction and customer confidence in the site. Delivery of the right products to customers will decrease time, costs, and workforce for the return process when the delivered products are wrong compared to the customer's orders.

Delivery time needs to be on time. Compared to shopping directly at the store or supermarket, customers can also receive their products with fast and timely delivery time without having to spend too much time moving. Also, to ensure the speed of delivery to customers, the site requires a large delivery force, understanding the transport process is an advantage to be able to deliver goods to customers in the fastest way.

\subsection{Post-possession convenience}

Convenience after purchase (post-possession convenience) is the weakest factor affecting customer satisfaction when shopping online (standardized beta $=0.099$ ). Compared to other impact factors, post-possession convenience needs durable solutions to increase the impact on the customer satisfaction process.

E-commerce websites must have a process for exchanging and returning products from buyers to retailers. In case the delivery is not the same as the original product ordered by the customer, the process of exchanging and returning the product to the retailer will be interested and done by customers. Therefore, it is necessary to specify the time to exchange and return, the form of shipping order for the exchange and return process, the method of contacting the retailer, the shipping and conversion costs that customers need to make to exchange and return products to retailers quickly.

There is an interaction of retailers on e-commerce websites: Problems around products that customers do not understand can contact the retailer directly for answers and problemsolving process. The customer's process is carried out quickly and promptly, ensuring the 
DOI: 10.14807/ijmp.v11i7.1251

shortening time for answering customers. The method to contact the retailer for distribution of products that customers order on the website is also clearly displayed, such as phone number, address, the manager.

\subsection{Buying intention and Electronic Word-Of-Mouth (E-WOM)}

Through the experience of online convenience, customers will feel satisfied. From there, customers will continue to shop online at that website. Besides, customer satisfaction will lead to customers using this website more often to make online purchases. Therefore, online customer satisfaction from online convenience (access convenience, search convenience, evaluation convenience, attentiveness convenience, transaction convenience, possession convenience, and post-possession convenience) is essential.

From online customer satisfaction, customers tend to perform electronic word-ofmouth. Customers share knowledge and information on online sales websites. Also, for other customers, they will read online consumer reviews of the old customers when they do online shopping. Finally, businesses will also receive more benefits and sell more when online loyalty customers recommend people to buy products online from the website where the online loyalty customers usually buy them.

\section{REFERENCES}

AJZEN I.; FISHBEIN M. (1975) Belief, Attitude, Intention and Behavior: An Introduction to theory and research, Addition-Wesley, Reading, MA.

AJZEN, I. (1991) The theory of planned behavior. Organizational Behavior and Human Decision Processes, v. 50 n. 2, p. 179-211.

ALBA, J.; LYNCH, J.; WEITZ, B.; JANISZEWSKI, C.; LUTZ, R.; SAWYER, A.; WOOD, S. (1997) Interactive home shopping: consumer, retailer, and manufacturer incentives to participate in electronic Marketplaces. Journal of Marketing, v. 61, n. 3, p. 38-53.

BEAUCHAMP, M. B.; PONDER, N. (2010) Perceptions of retail convenience for in-store and online shoppers, The Marketing Management Journal, v. 20, n. 1, p. 49-65.

BERRY, L. L.; SEIDERS, K.; GREWAL, D. (2002) Understanding Service Convenience. Journal of Marketing, v. 66, p. 1-17.

BHATNAGAR, A.; MISRA, S.; RAO, H. R. (2000) On Risk, Convenience, and Internet Shopping Behavior. Communications of the ACM, v. 43, p. 98-105.

CHATTERJEE, P. (2001) Online Reviews: Do Consumers Use Them? Advances in Consumer Research, v. 28, n. 1, p. 129-133.

CHAYAPA, K.; CHENG, L. W. (2011) Online Shopper Behavior: Influence of Online Shopping Decision. Asian Journal of Business Research, v. 1, p. 5-6.

CHEN, Y.; XIE, J. (2008) Online Consumer Review: Word-of-Mouth as a New Element of Marketing Communication Mix. Management Science, v. 54, n. 3, p. 477-491. 
DAVIS, F. D.; BOGOZZI, R. P.; WARSHAW, P. R. (1989) User acceptance of computer technology: A comparison of two theoretical models. Management Science, v. 35, p. 9821003.

DAVIS, F. D. (1989) Perceived usefulness, perceived ease of use, and user acceptance of information technology. MIS Quarterly, v. 13, p. 39-319.

DE KERVILER, G.; DEMOULIN, N. T. M.; ZIDDA, P. (2016) Adoption of in-store mobile payment: Are perceived risk and convenience the only drivers? Journal of Retailing and Consumer Services, v. 31, p. 334-344

DUARTE, P.; COSTA E SILVA, S.; FERREIRA, M. B. (2018) How convenient is it? Delivering online shopping convenience to enhance customer satisfaction and encourage eWOM. Journal of Retailing and Consumer Services, n. 44, p. 161-169.

ENGEL, J. F.; BLACKWELL, R. D.; KEGERREIS R. J. (1969) How information is used to adopt an innovation. Journal of advertising research, v. 9, n. 4, p. 3-8.

FORSYTHE, S.; LIU, C.; SHANNON, D.; GARDNER, L. C. (2006) Development of a scale to measure the perceived benefits and risks of online shopping. Journal of Interactive Marketing, v. 20, n. 2, p. 55-75.

GOYETTE, I.; RICARD, L.; BERGERON, J.; MARTICOTTE, F. (2010) E-WOM Scale: word-of-mouth measurement scale for e-services context. Canadian Journal of Administrative Sciences, v. 27, n. 1, p. 5-23.

GRUEN, T. W.; OSMONBEKOV, T. D.; CZAPLEWSKI, A. J. (2006) eWOM: The impact of customer-to-customer online know-how exchange on customer value and loyalty. Journal of Business Research, v. 59, n. 4, p. 449-456.

HAIR, F. J.; BACK, C. W.; BABIN, J. B.; ANDERSON, E. R. (2014) Multivariate Data Analysis, London, Pearson.

HENNIG-THURAU, T.; GWINNER, K. P.; WALSH, G.; GREMLER, D. D. (2004) Electronic word-of-mouth via consumer-opinion platforms: What motivates consumers to articulate themselves on the Internet? Journal of Interactive Marketing, v. 18, n. 1, p. 38-52.

JAVADI, M. H. M.; DOLATABADI, H. R.; NOURBAKHSH, M.; POURSAEEDI, A.; ASADOLLAHI, A. R. (2012) An analysis of factors affecting on Online shopping behavior of consumers. International Journal of Marketing Studies, v. 4, n. 5, p. 81-98.

JAYAWARDHENA, C.; WRIGHT, L. T.; DENNIS, C. (2007) Consumers online: Intentions, orientations and segmentation. International Journal of Retail and Distribution Management, v. 35, n. 6, p. 515-599.

JIANG, L.; YANG, Z.; JUN, M. (2013) Measuring consumer perceptions of online shopping convenience, Journal of Service Management, v. 24, n. 2, p. 191-214.

JUN, M.; YANG, Z.; KIM, D. (2004) Customers’ perceptions of online retailing service quality and their satisfaction. International Journal of Quality and Reliability Management, v. 21, n. 8, p. 817-840.

KATZ, E.; LAZARSFELD, P. F. (1955) Personal influence: the part played by people in the flow of mass communications. Free Press.

KING, S. F.; LIOU, J.-S. (2004) A framework for internet channel evaluation. International Journal of Information Management, v. 24, n. 6, p. 473-488. 
KUMAR, A.; KASHYAP, A. K. (2018) Leveraging utilitarian perspective of online shopping to motivate online shoppers. International Journal of Retail and Distribution Management, v. 46, n. 3, p. 247-263.

LAW, R.; HSU, C. H. C. (2006) Importance of hotel website dimensions and attributes: perceptions of online browsers and online purchasers. Journal of Hospitality and Tourism Research, v. 30, n. 3, p. 295-312.

LE-HOANG, V. P. (2020) The effects of electronic word-of-mouth (eWOM) on the adoption of eWOM information. Independent Journal of Management and Production, v. 11, n. 6.

LE-HOANG, V. P.; NGUYEN, Q. B.; LUU, X. D.; HO, T. V.; PHAN, T. N. (2019) Factors affecting online buying intention: The case of tiki.vn. Pacific Business Review International, v. 12, n. 4, p. 45-57.

LEE, J.; PARK, D.-H.; HAN, I. (2008) The effect of negative online consumer reviews on product attitude: An information processing view. Electronic Commerce Research and Applications, v. 7, n. 3, p. 341-352.

LI, N.; ZHANG, P. (2002) Consumer online shopping attitudes and behavior: an assessment of research. Proceedings of 8th Americas Conference on Information System, p. 508-517.

LUEDI, A. (1997) Personalize or Perish. Electronic Markets, v. 7, n. 3, p. 22-25.

MADU, C. N.; MADU, A. A. (2002) Dimensions of e-quality. International Journal of Quality and Reliability Management, v. 19, n. 3, p. 246-258.

MEIXIAN, L. (2015) Convenience and Online Consumer Shopping Behavior: A Business Anthropological Case Study Based on the Contingent Valuation Method. The Anthropologist, v. 21, n. 1-2, p. 8-17.

NUnNAlly, C.; BERnSTeIN, I. H. (1994) Psychometric theory, New York, McGrawHill Company.

PARK, C.; LEE, T. M. (2009) Information Direction, Website Reputation and eWOM Effect: A Moderating Role of Product Type. Journal of Business Research, v. 62, p. 61-67

PARK, C.; WANG, Y.; YAO, Y.; KANG, Y. R. (2011) Factors Influencing eWOM Effects: Using Experience, Credibility, and Susceptibility. International Journal of Social Science and Humanity, v. 1, n. 1, p. 74-79.

PARK, D.-H.; KIM, S. (2008) The effects of consumer knowledge on message processing of electronic word-of-mouth via online consumer reviews. Electronic Commerce Research and Applications, v. 7, n. 4, p. 399-410.

ROHM, A. J.; SWAMINATHAN, V. (2004) A typology of online shoppers based on shopping motivations. Journal of Business Research, v. 57, n. 7, p. 748-757.

SEIDERS, K.; BERRY, L. L.; GRESHAM, L. G. (2000) Attention, Retailers! How convenient is your convenience strategy? Sloan Management Review, v. 41, p. 79-90.

SEIDERS, K.; VOSS, G. B.; GODFREY, A. L.; GREWAL, D. (2007) SERVCON: development and validation of a multidimensional service convenience scale. Journal of the Academy of Marketing Science, v. 35, n. 1, p. 144-156.

SINHA, J.; KIM, J.(2012) Factors affecting Indian consumers' online buying behavior. Innovative Marketing, v. 8, n. 2, p. 46-57. 
TSAI, Y.; WU, S.-W. (2011) Using internal marketing to improve organizational commitment and service quality. Journal of Advanced Nursing, v. 67, n. 12, p. 2593-2604.

WOLFINBARGER, M.; GILLY, M. C.; (2001) Shopping online for freedom, control, and fun. California Management Review, v. 43, n. 2, p. 34-55.

ZEITHAML, V. A.; BERRY, L. L.; PARASURAMAN, A. (1996) The Behavioral Consequences of Service Quality. Journal of Marketing, v. 60, n. 2, p. 31. 